\title{
Two Novel Thermotolerant Methane Oxidizers from a Tropical Natural Gas Field in Bangladesh
}

\author{
Tajul Islam ${ }^{*}$, Maqsud Hossain ${ }^{2,3}$, Naushin Tabassum², Mahir Amer Haque ${ }^{3}$, Hasan Mahmud Reza ${ }^{4}$, Lise Øvreås ${ }^{1}$ \\ ${ }^{I}$ Department of Biological Sciences, Thormøhlens gate 53 A/B, Bergen-5020, University of Bergen, Norway, ${ }^{2}$ NSU Genome Research Institute (NGRI), Bashundhara, \\ Dhaka-1229, North South University, Bangladesh, ${ }^{3}$ Department of Biochemistry and Microbiology, Bashundhara, Dhaka-1229, North South University, Bangladesh, \\ ${ }^{4}$ Department of Pharmaceutical Sciences, Bashundhara, Dhaka-1229, North South University, Bangladesh.
}

\begin{abstract}
Aerobic thermotolerant methane oxidizers utilize methane as a sole carbon and energy source, and predominantly they are associated with the phylum Proteobacteria. Here we present two further new strains (HGS-45: coccusshaped and HGF-47: rod-shaped and vibrioid) of thermotolerant obligate proteobacterial methanotrophic bacteria, which were isolated from an abandoned tropical natural gas field wet soil sample in the northeast of Bangladesh. Strains are Gram-negative, nonmotile, and capable of growth on methane and methanol as their energy sources. Isolates are thermotolerant and could grow up to $52^{\circ} \mathrm{C}$, optimally at $42^{\circ} \mathrm{C}$, but show no growth at 55 or $15^{\circ} \mathrm{C}$. Based on 16S rRNA gene sequence analyses and phylogenetically, HGS-45 is most closely related to the obligate Type Ib methanotroph Methylococcus capsulatus of the family Methylococcaceae, whereas HGF-47 is affiliated to Type IIa methanotroph Methylocystis sp. of the family Methylocystaceae and possesses Type II intracytoplasmic membrane (ICM) systems. Genes of particulate methane monooxygenase (pMMO) and the methanol dehydrogenase (MDH) were detected by PCR. Southern-blot analyses of genomic DNA from both strains were positive, implying the aerobic biological oxidation process from methane to methanol by the pMMO. Each strain presumably represents a novel species. Furthermore, both strains will increase our knowledge of thermotolerant methanotrophic proteobacterial diversity, cohabitation, and their participation to global carbon cycles as well as signifying biological methane sinks in the terrestrial natural gas field ecosystems.
\end{abstract}

Key Words: thermotolerant, proteobacteria, methanotrophic.

\section{Introduction}

Methane, which plays a key role in the global carbon cycle, is about 34 times more potent than $\mathrm{CO}_{2}$ as a greenhouse gas and contributes a huge potential global climatic problem ${ }^{1}$. Abiogenic methane from Terrestrial geological sources (e.g. through seeps, rejected natural gas well-fields, gas venting or degassing of spring water) promote considerably large amounts of this important climate gas to the atmosphere ${ }^{2}$. Several terrestrial gas fields are situated in the north-east of Bangladesh. Some of the gas fields were formed in blowouts during the drilling, and became rejected because of irregularly high gas pressure or different technical reasons ${ }^{3}$. However, geological methane is still continously flowing out from these abandoned gas fields. Gas leakages due to accidents in the oil and gas sector can release large amounts of methane within short periods of time ${ }^{4}$. Such fields in the terrestrial tropical area may enhance the activity and structure of microorganisms in addition to methane eating bugs, and may have concequences of Earth's methane budget. Despite the fact that methane oxidizing bacteria (MOB) or methanotrophs are an environmentally important group of bacteria due to their critical role in reduction of methane emissions to the atmosphere from different ecosystems. These microorganisms have been reported to be ubiquitous in nature and isolated from a wide variety of thermal and non-thermal habitats. This group can be distinguished from other microorganisms by their unique capability of utilizing methane as sole carbon and energy source. They contain a unique multicomponent enzyme system called MMO (methane monooxygenase) that is classified into the two distinct types as a pMMO (particulate) and a sMMO (soluble). Until the present, research on methanotrophs have particularly emphasized on low temperature environments, and more than 60 type strains as cultivated representatives of mesophilic, psychrophilic or psychrotolerant growth at neutral $\mathrm{pH}$ were validly reported ${ }^{5,6}$. Currently, thermotolerant methane oxidizers with optimal growth temperatures between 30 and $44^{\circ} \mathrm{C}$ (a temperature range of $20-50^{\circ} \mathrm{C}$ ) have been reported in the phyla of Proteobacteria (seven species: Methylomarinum vadi, Methylococcus capsulatus, Mcc. chroococcus, Methylocaldum gracile, Mca. tepidum, Mca. marinum, and Methylocystis sp. strain Se48) and Verrucomicrobia (two species: Methyloacidiphilum cyclopophantes and Mac. tartarophylax $)^{6-14}$. Moreover, key functional genes ( $p m o A$, encoding the pMMO; mmoX: encoding the sMMO, and $m x a F$ : encoding the methanol dehydrogenase, $\mathrm{MDH}$ ) were commonly applied for detecting aerobic methanotrophs in the various habitats ${ }^{15,16}$. 
Strains Texas and Bath of the genus Mcc. capsulatus (growth optimum $\mathrm{T}_{\text {opt }}: 37^{\circ} \mathrm{C}$ and $\mathrm{T}_{\max }: 50^{\circ} \mathrm{C}$ ) are demonstrated to be thermotolerant Type Ib methanotrophs of the family Methylococcaceae, and were isolated from sewage sludge and geothermally heated water, respectively. Only the strain Bath is the most well-studied, so far, of all methanotrophs in regard to physiology, molecular genetics and ecology 17 . Alphaproteobacterial methanotrophs are mostly mesophilic or psychrotolerant and mainly isolated from low-temperature ecosystems ${ }^{18}$. Untill now, only a single thermotolerant methanotrophic strain Se48, in the family Methylocystaceae was reported, and was recovered through cutivation efforts using a mud sample from a neutral thermal spring in the Transbaikal territory (Russia). This strain is a new species of the genus Methylocystis and is able to grow at temperature ranging from $15-53^{\circ} \mathrm{C}$ with optimum growth at $37^{\circ} \mathrm{C}^{13}$. Moreover, slightly acidophilic gammaproteobacterial methanotrophs (strains BFH1 and $\mathrm{BFH} 2$ ) were also reported from tropical topsoil ( $\mathrm{pH} 5$ ) by leakage of natural methane from a gas field area at Horipur in Bangladesh, but both strains are moderately thermophilic rather than thermotolerant methane oxidizers. They grow optimally at 51 to $55^{\circ} \mathrm{C}$, and $16 \mathrm{~S}$ rRNA gene phylogeny confirmed them in a well-separated group making a cluster together with the genus Methylocaldum as the closest relatives ${ }^{19}$. Previously, the presence of thermotolerant methane oxidizers was not reported from terrestrial gas well-field soils. In the view of the fact that we attemped to recover extant methane consuming thermotolerant bacteria. In this present study, we demonstrate the isolation and primary description of two novel strains retrieved from an abandoned tropical gas field wet soil samples through cultivation efforts. They are obligately thermotolerant aerobic methane oxidizers and belonging to the phylum Proteobacteria.

\section{Materials and Methods}

\section{Sampling, Isolation and Cultivation Conditions}

A soil sample (approximately 40 grams) was collected $(20 \mathrm{~cm}$ below the ground surface) using a sterile Falcon tube from a rejected natural gas field in Sylhet, Bangladesh in July 2009. This exploded gas field (Sylhet-2) in Horipur is situated in a small village (at the side of Shikarkhan-Ultarpar road; $24^{\circ} 58^{\circ} 55.0^{\prime \prime} \mathrm{N} 92^{\circ} 01^{\prime} 56.4^{\prime \prime E}$, Figure $\mathrm{S} 1$ ) in the subdivisionJaintapur. The gas field was affected by blowouts during the drilling in 1962 and abandoned ${ }^{3}$. The $\mathrm{pH}$ and temperature of wet soil were measured by using a $\mathrm{pH}$ meter (MP220, Mettler Toledo) and a digital temperature sensor (Digitron, 2000T, Sifam Instruments, UK), respectively. On the day of sampling, the soil was frozen $\left(-20^{\circ} \mathrm{C}\right)$. To prevent as much growth of mesophilic methanotrophs in the enrichment, we utilized $45^{\circ} \mathrm{C}$ as the incubation temperature. For producing the primary enrichment of thermotolerant methanotrophic populations, 3 grams of wet soil was inoculated directly into 20 $\mathrm{mL}$ of a low-salt mineral medium (LMM and $\mathrm{pH}$ 6.8) in a 120 $\mathrm{mL}$ serum vial ${ }^{20}$. The sterile serum vial was locked with a butyl rubber cap with an aluminium crimped seal and incubated under a mixture of methane-air (80-20\%) atmosphere in the headspace (purity of methane, $99.5 \%$, Yara Praxair, Oslo, Norway) at $45^{\circ} \mathrm{C}$ for three weeks without shaking. The gas mixture was replaced every 7 days. The primary enrichments became visibly turbid and were verified by phase-contrast microscopy (Eclipse E400 microscope, Nikon Corporation, Tokyo, Japan). Afterwards, 2 $\mathrm{mL}$ from the enrichment was transferred to fresh $20 \mathrm{~mL}$ LMM and incubated at the same growth conditions. After the $5^{\text {th }}$ passages of subculturing at same culture conditions, cell suspensions were serially diluted and plated onto LMM containing gelrite solidified plates $\left(20 \mathrm{~g} \mathrm{~L}^{-1}, \mathrm{GelZan}^{\mathrm{TM}} \mathrm{CM}\right.$, Sigma-Aldrich). The plates were incubated in a glass jar containing about $80 \%$ methane and $20 \%$ air at $45^{\circ} \mathrm{C}$. After three weeks of incubation, colonies were picked and streaked onto new plates. Selected colonies were also examined by a phase-contrast microscope. Finally, picked colonies were used to make dilution series up to the order of $10^{-8}$ on to the microtiter plates. Both LMM and LMA were also used for regular cultivations with methane-air in the head space at $45^{\circ} \mathrm{C}^{19}$. Purity of both strains was evaluated by observation of a single colony growth on gelrite plates atmosphere without methane, on R2A agar plates ${ }^{21}$, and repeated 16S rRNA gene sequencing analysis as well as using phase-contrast microscopy and electron microscopy.

\section{Growth Conditions, Acetylene Inhibition Test and Naphthalene} test

Various organic compounds, as a carbon source, were tested in liquid LMM supplemented with sterile multicarbon substrates (ethanol, acetate, pyruvate, succinate, methylamine, glucose, fructose, and yeast extract) at a concentration of $10 \mathrm{mM}$. Growth on methanol and formate was tested using LMM containing substrate concentrations of $0.1,0.2,0.25$, and $0.5 \%(\mathrm{v} / \mathrm{v})$. The tests of antibiotic susceptibility were evaluated a 10-day period incubation $\left(10 \mu \mathrm{g} \mathrm{mL}^{-1}\right.$ : ampicillin, tetracycline, streptomycin, erythromycin; $30 \mu \mathrm{g} \mathrm{mL}^{-1}$ : kanamycin and nalidixic acid). In addition, growth was also examined by replacing $\mathrm{NH}_{4} \mathrm{Cl}$ and $\mathrm{KNO}_{3}$ in both LMM and LMA in triplicate with $\mathrm{N}_{2}$ from the air (20\% air in the headspace) and methane. The generation time and the optical density $(600 \mathrm{~nm})$ were assessed. To verify the acetylene inhibition test, strains $M$. capsulatus Bath, $M$. kamchatkense Kam 1 and Methylococcaceae Type $\mathrm{Ib}$ methanotroph strain BFH1 were used as positive controls under the same assay conditions ${ }^{22,23} .4 \%(\mathrm{v} / \mathrm{v})$ acetylene was added in the headspace of three replicate bottles after incubation with methane and LMM. One bottle was used without adding acetylene as a control. The naphthalene-oxidation assay was performed for the verification of sMMO in LMM without copper ${ }^{24} . M$. capsulatus Bath and strain BFH1 were employed as positive control and as negative control of the assay, respectively ${ }^{18}$. The morphology of cells was determined using phase-contrast microscopy. 


\section{Electron Microscopy, Fatty Acid Analysis and G+C Content Measurement}

Exponentially grown cells (only HGF-47) were used to prepare ultrathin sections as described previously ${ }^{22}$. Fatty acid analysis was completed by the Identification Service of the Deutsche Sammlung von Mikroorganismen und Zellkulturen $\mathrm{GmbH}$ (DSMZ, Braunschweig, Germany). Strains HGS-45 and HGF47 were grown under optimal conditions and shipped to DSMZ, where the samples were processed further. The DNA base composition $(\mathrm{G}+\mathrm{C}$ content, mol \%) of the strain HGF-47 was determined by DSMZ.

\section{PCR amplification and Southern blot hybridization of functional} genes

Genomic DNA from both strains was extracted using GenElute Bacterial Genomic DNA kit (Sigma). The 16S rRNA genes, using the primer set $27 \mathrm{f}$ and $1492 \mathrm{r}$, were amplified as described previously using a Veriti 96 well thermal cycler (Applied Biosystems; Table S1 $)^{25}$. The PCR products were purified and sequenced using the Big dye kit for automated DNA sequencers (ABI 3700 PE; Applied Biosystems). The genes encoding particulate methane monooxygenase ( monooxygenase ( $\mathrm{mmoX}$ ), and methanol dehydrogenease ( $\mathrm{mxaF}$ ) were also PCR amplified from genomic DNA using primers listed in PCR conditions, which was described previously ${ }^{19}$ (Supplementary Table S1). Nucleotide (nt) sequences of the $16 \mathrm{~S}$ rRNA gene were compared with available sequences in the GenBank database using the NCBI tools (Blastn). For further confirming of pMMO and sMMO, the Southern blotting hybridization technique was utilized. Genomic DNA from strains HGS-45 and HGF-47, Methylococcaceae Type Ib strain LS7$\mathrm{MC}^{26}$, Methylococcaceae Type $\mathrm{Ib}$ strain $\mathrm{BFH} 1^{19}, M$. kamchatkense $\mathrm{Kam}^{22}$ (as a negative control) and M. capsulatus Bath (as a positive control) was extracted (Supplementary Table S2). Then, DNA was digested with EcoRI and HindIII. Hybridization probes and the further process were followed as previously described.

\section{Phylogenetic Analyses}

16S rRNA gene (HGS-45: $1433 \mathrm{nt}$ and HGF-47: $1385 \mathrm{nt}$ ) sequences were aligned using CLUSTAL $\mathrm{W}$ algorithm as implemented in the MEGA7 software package ${ }^{27}$. To make sure the phylogenetic affiliation, trees of the 16S rRNA gene and sequences were constructed using the Maximum-Likelihood (ML), Minimum-Evolution (ME) and Neighbor-Joining (NJ). The evolutionary distances were computed using the methods like the Jukes-Cantor method, Kimura 2-parameter and Maximum Composite Likelihood, which are also implemented in the MEGA7 software. The trees topology was decided by 1000 bootstrap replications. Nucleotide sequences determined in this study were deposited in the GenBank database. The accession numbers are as follows: for strain HGS-45: MZ267055 (16S rRNA) and for strain HGF-47: MZ267054 (16S rRNA).

\section{Results and discussion}

The $\mathrm{pH}$ and in situ temperature of the sample were 6.96 and $38.3^{\circ} \mathrm{C}$, respectively. Inoculation at $45^{\circ} \mathrm{C}$ with wet soil and methane, after three weeks, microbial growth in the primary enrichments was observed (a density of about $10^{8}$ cells $\mathrm{mL}^{-1}$ ), and cells were confirmed by a phase-contrast microscope. In the primary and secondary enrichments, long rod-shaped cells with endospore (about 4 to $6 \mathrm{im}$ ) were observed, but they were not seen in the tertiary enrichments anymore. Two different colours of colonies (white: about $1-1.2 \mathrm{~mm}$ in diameter and light yellow and shiny: $1.3-1.5$ in diameter) appeared on the gelrite plates. From growth of cells (selected colonies) with methane on the microtiter plates of dilution $10^{-8}$, we were able to isolate two different strains, termed as HGS-45 and HGF-47, from a natural gas well-field wet soil. Strains did grow robust on methanol $(0.2 \%)$ but no growth was seen with any multicarbon substrates, thus, demonstrating that strains are obligate aerobic methylotrophic bacteria and grow only on methane and methanol as the energy and carbon source. Heterotrophic contaminants were not observed on these media or gelrite plates. No growth was found without methane or methanol under aerobic conditions, and with methane or methanol under anaerobic conditions. Vitamins were not imperative for growth. They showed optimal growth on both LMM and LMA, and these media are generally 10 times diluted than NMS and $\mathrm{AMS}^{28}$. Strains could grow up to $52^{\circ} \mathrm{C}$, optimally between 40 and $42^{\circ} \mathrm{C}$, but did not grow at 55 or $15^{\circ} \mathrm{C}$. The $\mathrm{pH}$ range of HGS-45 and HGF-47 was 6.0"8.5 (optimum 7.0) and 6.0"8.8 (optimum 6.7"7.3), respectively. The specific growth rates (i) of HGS-45 and HGF-47 were determined to be 0.087 and 0.063 , respectively. Growth did not occur by testing antibiotics. Cells utilized nitrate, ammonium or atmospheric $\mathrm{N}_{2}$ as a nitrogen source. We observed that cells grew better with LMM containing $\mathrm{KNO}_{3}$ rather than with LMA containing $\mathrm{NH}_{4} \mathrm{Cl}$. Acetylene acts an inhibitor that is generally used for completely preventing growth of methanotrophs ${ }^{26,29}$. Growth of both strains was impeded after adding $4 \%$ acetylene in the headspace. This observation can be compared to other aerobic methane oxidizers (both proteobacterial and verrucomicrobial methanotrophs), which indicates the presence of functional methane monooxygenase (MMO) enzyme systems $^{22,26}$.

Physiological properties of strains, compared to related thermotolerant proteobacterial methanotrophs, are presented in Table 1. Cells were Gram-negative, nonmotile, divided by binary division. Strain HGS-45 is coccus-shaped (Figure 1a), but strain HGF-47 is vibrioid-shaped and occurred individually. No aggregations of strain HGS-45 were seen, but some aggregations were observed for the strain HGF-47. TEM analysis of HGF-47 showed Gram-negative cell wall, and the presence of the Type II intracytoplasmic membrane (ICM) system appearing as paired of membranes aligned to the periphery (Figure 1c), which is observed in Type IIa methanotrophs (genus: Methylocystis) of 
the family Methylocystaceae ${ }^{30,31}$ (Mcy. hyeri, Mcy. rosea). Type II ICMs in Methylocystis species are responsible for methane oxidation. A large storage granule (most possibly poly-âhydroxybutyrate), in most cells of strain HGF-47, has been observed in the analyses of TEM and scanning micrographs (Figure 1c, d).

Fatty acids profile comparison of both strains and other related thermotolerant species are presented in Table 2 . The predominant fatty acids of strain HGS- 45 were $\mathrm{C} 16: 1 \grave{u} 7 c(30.82 \%)$ and C16:0 $(49.34 \%)$ that accounting for $80 \%$ of the total amount of fatty acids. C16:0 is normally found in the genera Methylococcus, Methylocaldum, and Methylococcaceae strain BFH1 (thermotolerant and thermophilic: about 33-63\%) of Type Ib methanotorphs of the family Methylococcaceae. Although $\mathrm{C} 16: 1 \grave{u} 7 c$ is lacking in Methylocaldum spp., but 10-23\% and $14 \%$ of it were found in Methylococcus sp. and strain BFH1, respectively ${ }^{11,18}$. About $31 \%$ of $\mathrm{C} 16: 1 \omega 7 c$ has not been previously reported in any described thermotolerant methanotrophs of Type Ib, whereas Methylococcaceae strain LS7MC (thermophilic), Methyloparacoccus murrellii and Methylomagnum ishizawai contain more than $41 \%$ of it, and they were defined as moderately thermophilic and mesophilic methanotrophs, respectively ${ }^{26,32,33}$. The PLFA profiles of strain HGF-47 deviated significantly from mesophilic type IIa methanorophic species of the genus Methylocystis (Table 2). The

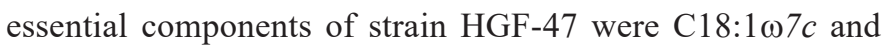
$\mathrm{C} 18: 1 \omega 9 c$ fatty acids. These were also found in a thermotolerant methanotrophic Methylocystis strain Se48, which was recovered from a thermal spring ${ }^{12}$ (Tsyrenzhapova et al., 2007). In the genera Methylocystis and Methylosinus contain predominantly

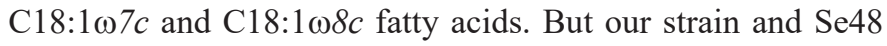
lack of $\mathrm{C} 18: 1 \dot{u} 8 c$. Although, this fatty acid is common and specific marker to the genera Methylosinus and Methylocystis ${ }^{12,34}$.

PCR amplification reactions of functional genes provided positive results except the gene mmoX of strain HGF-47 (Supplementary Table S1). In the naphthalene assay, strain HGS-45 and HGF-47 displayed a positive and a negative colorimetric response, respectively. Furthermore, the analysis of Southern blotting from genomic DNA showed positive signals with the $\mathrm{pmoA}$ and $\mathrm{mmoX}$ probes of strain HGS-45, concurrently the $m m o X$ probe did not yield any positive signals of strain HGF-47 (Supplementary Table S2). These results assure that strain HGS-45 contains the soluble form of MMO, but strain HGF-47 does not have sMMO activity. The present of soluble methane monooxygenase enzyme in the strain HGS-45 was also verified using PCR amplification (Supplementary Table S1), Southern hybridization (Supplementary Table S2), and the naphthalene assay, indicating the significant conformity with the thermotolerant genus Methylococcus. This soluble form of MMO is widely found either in thermotolerant ${ }^{7}$ or mesophilic $\mathrm{MOB}^{18,33,35}$, but not in moderately thermophilic methane oxidizers ${ }^{19,26}$ or mesophilic Type Ib methanotrophs ${ }^{20}$. These findings assure that strain HGS45 is, most possibly, not a new species or subspecies of the moderately thermophilic Type Ib strains LS7-MC ${ }^{26}$ (Methylococcus-like) or BFH $1{ }^{19}$ (Methylocaldum-like) or other genera of the families Methylomonadaceae Type Ia,
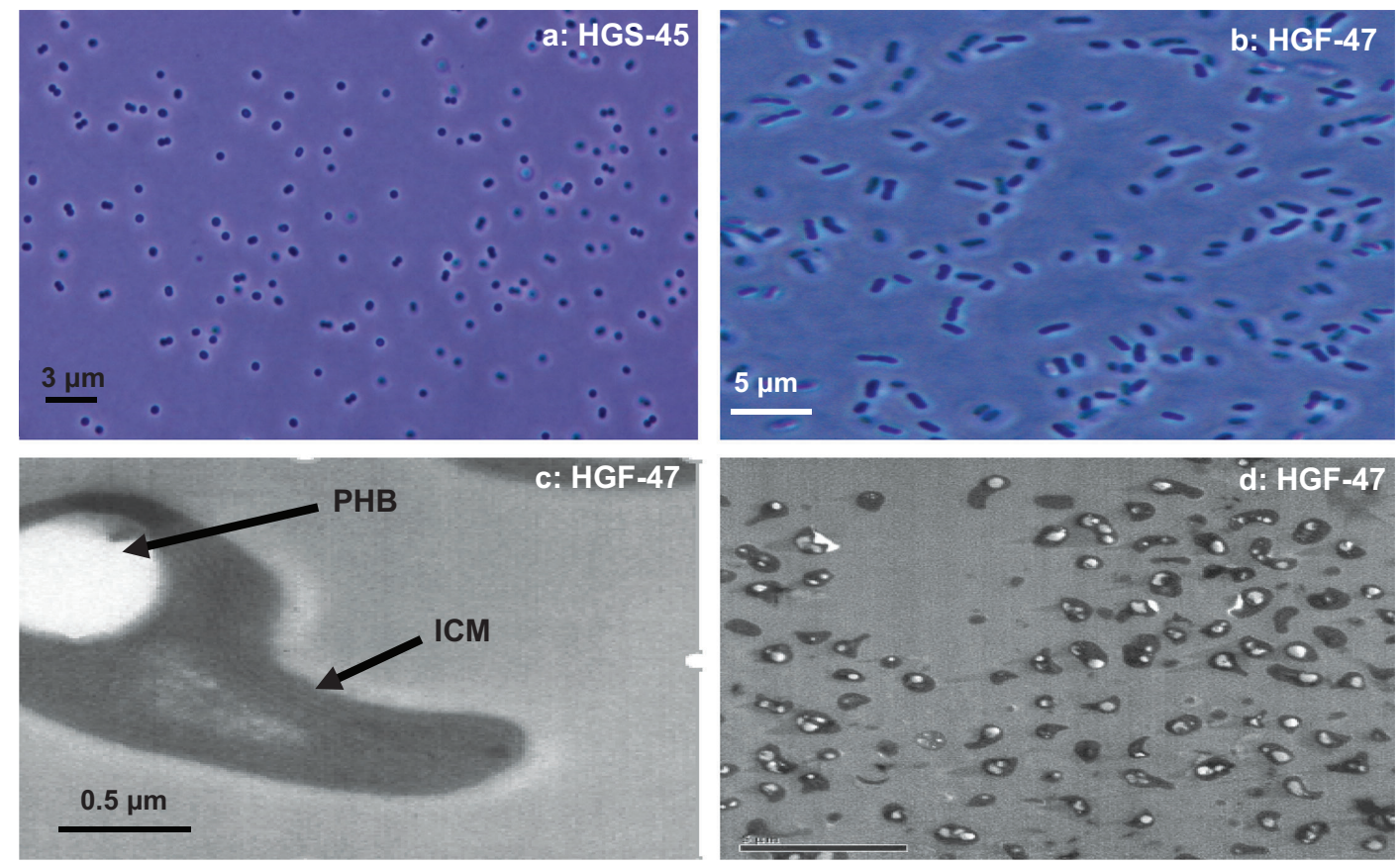

Fig. 1. Cell morphology. (a) and (b) Phase-contrast micrographs of strains HGS-45 (a coccus and a diplococcus) and HGF-47 (rod and vibrioid) at $1000 X$ magnification, respectively. Both strains were grown in LMM with methane for 5 days. (c) Transmission electron microscopy of ultra-thin sections of the strain HGF-47 and showing Type II intracytoplasmic membrane (ICM) systems and a poly-â-hydroxybutyrate intracellular granule (PHB). (d) A scanning electron micrograph (SEM) of the strain HGF-47. Scale bars: (a) $3 \mu \mathrm{m}$ (b) $5 \mu \mathrm{m}$ (c) $0,5 \mu \mathrm{m}$ and (d) $5 \mu \mathrm{m}$. 
Methylococcaceae Type Ib and Methylothermace Type Ic within the order Methylococcales.

Using Blastn search of the 16S rRNA gene sequence, strain HGS45 revealed a high sequence identity of $98.54 \%$ to $M c c$. capsulatus strain Texas (GenBank Accession No. NR_042183) and $98.47 \%$ to Mcc. capsulatus strain Bath complete genome (AE017282). The strain showed also 98.05 - 97.69\% sequence identity to clones of uncultured bacteria from fractured water of a gold mine borehole in the USA (JX434221, JX434221, JX434214, JX434181, JX434258, and JX434207), naturally

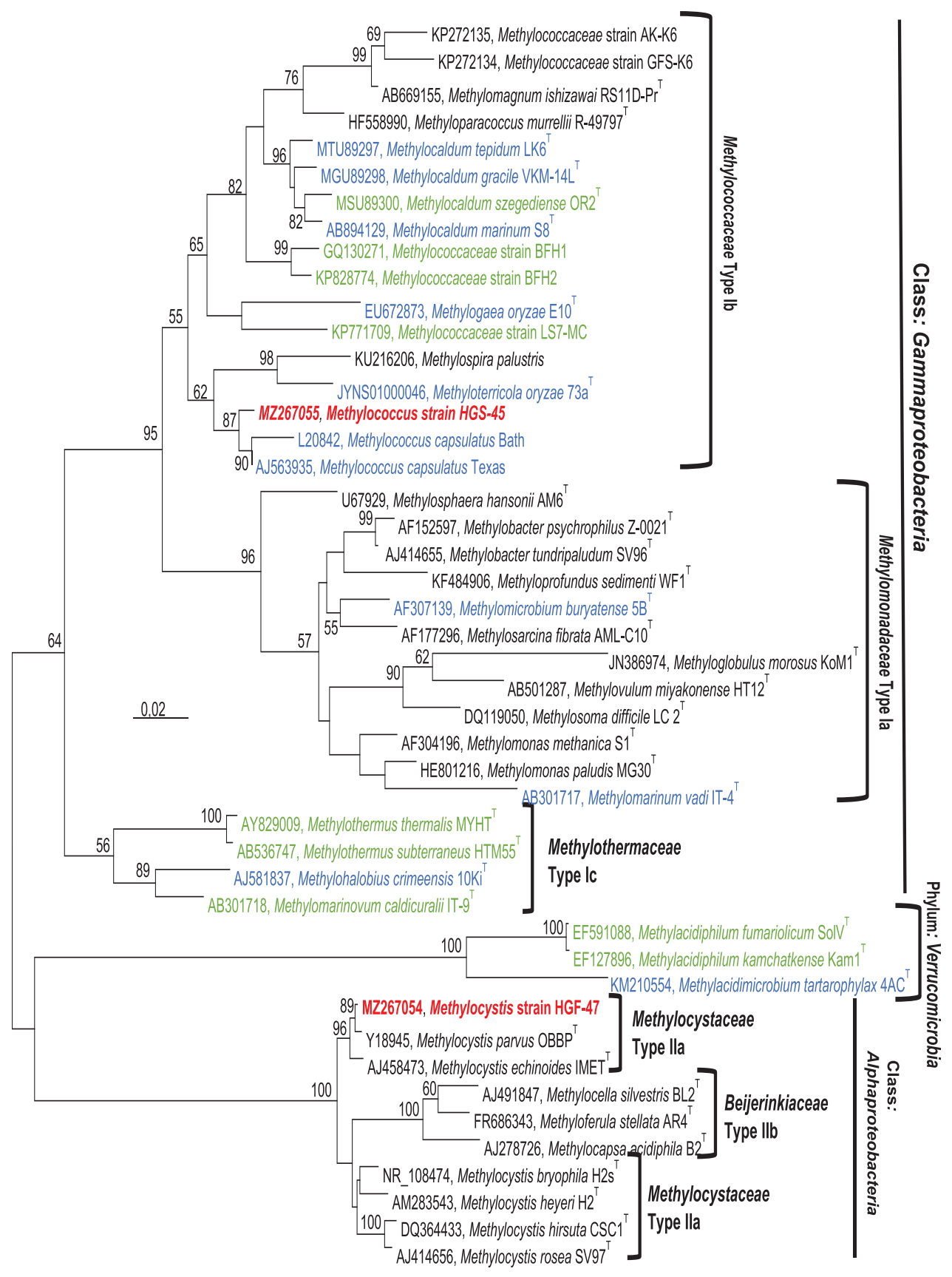

Fig. 2. Maximum-Liklihood (ML) tree. A $16 S$ rRNA gene-based phylogenetic tree of methanotrophic strains HGS-45 and HGF-47 (indicated in bold red) and representatives from the families Methylomonadaceae (Type Ia) and Methylococcaceae (Type Ib) of the class Gammaproteobacteria, and Methylocystaceae (Type IIa) of the class Alphaproteobacteria using MEGA7 software package. The tree is created with the Jukes-Cantor model and nodes supported by bootstrap values (percentages of 1000 data resamplings) e" $50 \%$ are shown at each node. The scale bar denotes 0.02 changes per nucleotide position. The analysis involved 46 nucleotide sequences. There were a total of 1180 positions in the final dataset. Evolutionary analyses were accomplished in MEGA $7^{27}$. Verrucomicrobial methanotrophs were used as an outgroup. Green: moderately thermophilic methanotrophs; blue: thermotolerant methanotrophs ${ }^{6}$. 
composting sugarcane bagasse piles in Thiland ${ }^{36}$, and fracturederived groundwater in a deep gold mine of South Africa ${ }^{37}$ (DQ088732). The high sequence identity of Mcc. capsulatus strains to HGS-45 suggests that they may have familiar physiology and metabolism features. Values of 16S rRNA gene sequence analysis by pairwise alignment of the strain HGS-45 and the cultured strains showed the most closest similarity with $\mathrm{Mcc}$. capsulatus Texas (98.5\%), Methylococcaceae strain BFH2 (93.7\%), Methyloterricola oryzae $73 \mathrm{a}^{\mathrm{T}}(93.5 \%)$, Mcd. marinum $\mathrm{S}^{\mathrm{T}}$ (93.4\%), Methylococcaceae strain LS7-MC (93.2\%) Mcd. gracile VKM-14L $\mathrm{L}^{\mathrm{T}}$ (92.9\%), Methylococcaceae strain BFH1 (92.8\%) Mcd. szegediense OR2 ${ }^{\mathrm{T}}$ (92.6\%) (Supplementary Table S3). The phylogenetic analysis of $16 \mathrm{~S}$ rRNA gene sequences using Neighbor-Joining tree revealed that strain HGS-45 was grouped in the genus Methylococcus of the family Methylococcaceae Type $\mathrm{Ib}$ (Figure 3). The same analysis situs was also established in the Minimum-Evolution (Supplementary Figure S2) and NeighbourJoining (Supplementary Figure S3) trees, indicating that the $16 \mathrm{~S}$ rRNA phylogeny performed an uniform position between strain HGS-45 and other related Type Ib methane oxidizers of the famliy Methylococcaceae. Furthermore, it was also suggested that strain HGS-45 is not a member of other described methanotrophic genera in the families either Methylomonadaceae Type Ia or Methylothermaceae Type Ic of the class Gammaproteobacteria.

Strain HGF-47, analysis of the the 16S rRNA gene sequence using Blastn, showed also a relatively high sequence identity of $99 \%$ $\%$ to the Methylocystis species (AJ868421, AJ458508, JX505249,
CP04433, MN511720, AF150805, NR_044946, NR_025544, HF558988, AF150790 and NR_025544) ${ }^{30,38-40}$. In addition, pairwise sequence alignment analysis of 16S rRNA gene sequences of strain HGF-47 revealed the most closest represented species like Methylocystis parvus $\mathrm{OBBP}^{\mathrm{T}}(99.1 \%)$, Methylocystis echinoides $\operatorname{IMET}^{\mathrm{T}}$ (98.7\%), Methylocystis hirsuta $\mathrm{CSC}^{\mathrm{T}}$ (97.5\%), Methylocystis rosea $\mathrm{SV}^{7} 7^{\mathrm{T}}$ (97.3\%), Methylocystis heyeri $\mathrm{H}_{2}{ }^{\mathrm{T}}$ (97.1\%), Methylocystis bryophila $\mathrm{H} 2 \mathrm{~s}^{\mathrm{T}}(97.0 \%)$ (Supplimentary Table S3). This signifies that our strain possibly denotes a new species in the genus Methylocystis of the family Methylocystaceae IIa. The 16S rRNA gene trees of strain HGF47 demonstrated the same topologies (Figure 2, S2 and S3), illustrating that this strain is not a member of other reported methanotrophic genera in families of Beijerinkiaceae (Phylum: Alphaproteobacteria) or Methylococcaceae Type Ib (Phylum: Gammaproteobacteria).

Phylogenetic analysis of the 16S rRNA gene of both strains, HGS45 and HGF-47, uncovered that they are feasibly new species within the orders Methylococcales and Rhizobiales, respectively. Furthermore, this phylogenetic deduction was assisted by the physiological properties and cellular PLFA analyses (Table 1 and Table 2). The recovered isolates are thermotolerant and obligate methylotrophs, because they are capable of growing on either methane or methanol. Furhter both strains are not mesophilic or actual thermophilic, as they are not able to grow optimally at $30^{\circ} \mathrm{C}$ or above $55^{\circ} \mathrm{C}$.

Table 1. Comparison of the major characteristics of the strains HGS-45 and HGF-47 with other described aerobic Thermotolerant methanotrophs

\begin{tabular}{|c|c|c|c|c|c|c|c|c|}
\hline Characteristic & 1 & 2 & 3 & 4 & 5 & 6 & 7 & 8 \\
\hline Cell morphology & Coccus & Coccus & Rod/pleomorphic & Rod/pleomorphic & Rods/coccus & Rods/coccus & Vibrioids & Rod/vibrioids \\
\hline Temperature condition & Thermotolerant & Thermotolerant & Thermotolerant & Thermotolerant & Thermotolerant & Thermotolerant & Thermotolerant & Thermotolerant \\
\hline Internal membranes & Type I & Type I & Type I & Type I & Type I & Type I & Type II & Type II \\
\hline Poly-â-hydro xy-butyrate & “ & “ & “ & “ & “ & “ & + & + \\
\hline Motility & “ & “ & + & + & “ & “ & “ & “ \\
\hline Pigmentation & White & Light yellow & Light brown & Light brown & Brown & Brown & white & Light yellow \\
\hline pMMO & + & + & + & + & + & + & + & + \\
\hline sMMO & + & + & “ & “ & + & + & “ & “ \\
\hline Growth on $\mathrm{N}$-free medium & + & + & + & + & + & + & ND & + \\
\hline Temperature range (opt.) & $20-52(40-42)$ & $20-50(37-42)$ & $30-47(42)$ & $30-47(42)$ & $20-47(36)$ & $20-44(37-43)$ & $15-53(37)$ & $18-52(40-42)$ \\
\hline pH growth range (optimal) & $6.0-8.5(7.0)$ & $5.5-7.5(6.5)$ & $5.5-7.5(6.5)$ & $5.5-7.5(6.5)$ & $6.0-8.0(7.0)$ & $4.5-8.1(6.2-7.0)$ & $5.0-7.5(5.5-6.8)$ & $6.0-8.8(6.5 " 7.3)$ \\
\hline Growth on methanol & + & + & “ & “ & + & + & + & + \\
\hline $\mathrm{G}+\mathrm{C}$ content $(\mathrm{mol} \%)$ & nd & 62.5 & 57.2 & 57.2 & 59.7 & 59.7 & 62 & 64.9 \\
\hline $\mathrm{G}+\mathrm{C}$ content $(\mathrm{mol} \%)^{\mathrm{a}}$ & 59.4 & 60.3 & 56.7 & 56.7 & 58 & 59.7 & nd & nd \\
\hline \multirow[t]{2}{*}{ Habitats } & Gas field & Soil and & Soil and & Soil & Marine & Marine & Thermal & Gas field \\
\hline & wet soil & thermal water & freshwater & & sediments & sediments & spring mud & wet soil \\
\hline
\end{tabular}

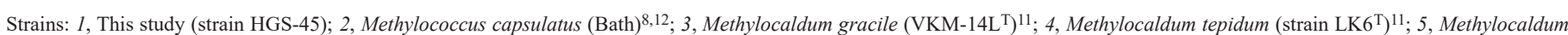

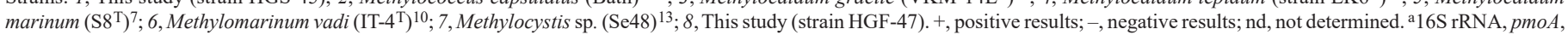
and $m m o X$ genes sequences were used for computing measurements of DNA G+C content (mol\%). 
Two Novel Thermotolerant Methane Oxidizers from a Tropical Natural Gas Field

Table 2. Fatty acids comparison of the strains HGS-45, HGF-47 and other related aerobic thermotolerant methanotrophs.

\begin{tabular}{|c|c|c|c|c|c|c|c|c|c|}
\hline Fatty acids & 1 & 2 & 3 & 4 & 5 & 6 & 7 & 8 & 9 \\
\hline C13:1 & 0.4 & & & & & & & & \\
\hline $\mathrm{C} 14: 0$ & 1.97 & $0.8-0.62$ & & & & & & & \\
\hline C15:0 & 0.64 & $0-1.7$ & & & & & & & \\
\hline $\mathrm{C} 16: 1 \omega 8 c$ & & & & & & 29.03 & & & \\
\hline $\mathrm{C} 16: 1 \omega 7 c$ & 30.82 & $10.6-23.1$ & & & & 3.39 & & 0.51 & $0.3-14.2$ \\
\hline $\mathrm{C} 16: 1 \omega 6 c$ & & $3.9-12.3$ & & & & & & & \\
\hline $\mathrm{C} 16: 1 \omega 5 c$ & 9.22 & $3.2-9.0$ & & & & & & & \\
\hline $\mathrm{C} 16: 1 \omega 5 \mathrm{t}$ & & $1.8-6.0$ & & & & 2.75 & & & \\
\hline C16:0 & 49.34 & $33.5-56.0$ & 43.4 & nd & 59.2 & 1.24 & & 0.98 & $0.7-5.1$ \\
\hline C16:1 & & & 45.9 & nd & 39.7 & & & & \\
\hline 9-o-Me-C16:0 & & $0-14.0$ & & & & & & & \\
\hline 10-o-Me-C16:0 & & & & & & 3.46 & & & \\
\hline $\mathrm{C} 16: 03 \mathrm{OH}$ & 2.34 & & & & & & & & \\
\hline $\mathrm{C} 17: 1 \omega \sigma c$ & & $0-1.8$ & & & & & & & \\
\hline $\mathrm{C} 17: 1 \omega 5 c$ & 4.57 & & & & & & & & \\
\hline 11-o-Me-17:0 & & $0-2.1$ & & & & & & & \\
\hline C18:0 & 0.72 & & & & & & & 0.63 & $0-5.0$ \\
\hline C18:1 & & $0-6.5$ & & & & & & & \\
\hline $\mathrm{C} 18: 1 \omega 9 t$ & & & & & & 14.67 & & & \\
\hline 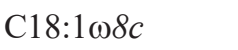 & & & & & & 31.98 & & & $52.9-73.6$ \\
\hline $\mathrm{C} 18: 1 \omega 7 c$ & & $0-2.9$ & & & & 10.8 & 33 & 39.26 & $14.8-37.7$ \\
\hline $\mathrm{C} 18: 1 \omega 9 c$ & & $0.6-1.8$ & & & & & 60 & 58.45 & \\
\hline C19:0cyc & & & & & & & & 0.17 & \\
\hline
\end{tabular}

Strains: 1, This study (strain HGS-45); 2, Methylococcus capsulatus ${ }^{12} ; 3$, Methylocaldum gracile (VKM-14L $\left.{ }^{\mathrm{T}}\right)^{11} ; 4$, Methylocaldum tepidum $\left(\mathrm{LK}^{\mathrm{T}}\right)^{11} ; 5$, Methylocaldum marinum $\left(\mathrm{S}^{\mathrm{T}}\right)^{7} ; 6$, Methylocystis heyeri $\left(\mathrm{H}_{2}^{\mathrm{T}}\right)^{30} ; 7$, Methylocystis $\mathrm{sp}$. $(\mathrm{Se} 48)^{13} ; 8$, This study (strain HGF-47); 9, Methylosinus and Methylocystis ${ }^{11}$. Values are given as a percentage of total fatty acids. Bold values show significant fatty acids. nd, not determined.

\section{Conclusion}

Mesophilic, psychrophilic and some moderately thermophilic aerobic methane oxidizing bacteria were validly described or reported. There are only a very few reported thermotolerant methane consuming bacteria with optimal growth temperature of $42{ }^{\circ} \mathrm{C}$ in the phyla Proteobacteria and Verrucomicrobia ${ }^{5}$ (Figure 2). In this study, two more novel thermotolerant methanotrophic bacteria, strains HGS-45 and HGF-47 were recuperated from an abandoned tropical natural gas field wet soil samples in the north-east of Bangladesh. Both novel isolates show an obligate aerobic methylotrophic growth with methane and methanol as the sole carbon and energy sources and encompass the particulate methane monooxygenase (pMMO) in the methane oxidation process. In addtion, the strain HGS-45 also processes the soluble methane monooxygenase (sMMO) and methanol dehydrogenase (MDH). In consistent with the anyalysis of $16 \mathrm{~S}$ rRNA gene and the detection of $p m o A$ and mxaF together with biochemical tests, the strain HGS-45 is probably a new species in the genus Methylococcus of the family Methylococcaceae Type Ib methanotroph, whereas HGF-47 might also be a new species in the genus Methylocystis of the family Methylocystaceae Type IIa methanotroph. Both strains indicate a significant role in the previously unrecognized biological methane sink, proteobacterial thermotolerant diversity, and on the adaptation of this process to natural gas field environments. Moreover, this study may increase our perception about methane consuming bacteria in the terrestrial natural gas field territories, and future complete genome sequencing of the species may contribute insights into their adaptation, and ecophysiological significance as well as for feasible biotechnological application.

Supplementary Materials: Table S1: Primers for amplification of functional genes. Table S2: Results of Southern blot evaluation of radioactively labeled $p m o A$ and $m m o X$ probes. Table S3: Pairwise sequence alignment analysis of $16 \mathrm{~S}$ rRNA gene sequences (https:/www.ebi.ac.uk/Tools/psa/emboss_water/). Figure S1: A 16S rRNA gene phylogeny (Minimum Evolution). Figure S2: A 16S rRNA gene phylogeny (Maximum Likelihood).

Author Contributions: T. I. designed the experiments, T.I, M.H., N.T., M. A. H., H. M. R., and L. Ø. wrote, edited the manuscript and analysed the data. T. I. collected sample and performed the 
isolation of strains and carried out morphological, physiological and phylogenetic analyses. L. Ø. contributed reagents/materials/ TEM/sequencing analysis/cultivation facilities. All authors read and approved the published version of the manuscript.

\section{Acknowledgements:}

The electron microscopy imaging was performed at the Molecular Imaging Center (MIC), Department of Biomedicine, University of Bergen. Norway.

\section{Funding:}

This research received no external funding.

\section{Conflicts of Interest:}

The authors declare that they have no conflict of interests.

\section{References}

1. IPCC. Climate Change:The Physical Science Basis, Contribution of Working Group I to the Fith Assessment Report of the IPCC. Cambridge University Press: Cambridge, UK, 2013.

2. Nazaries L, Murrell JC, Millard P, Baggs L and Singh BK. 2013. Methane, microbes and models: Fundamental understanding of the soil methane cycle for future predictions. Environ Microbiol 15: 2395-2417.

3. Khan MAI and Nasir FB. A review over major gas blowouts in Bangladesh, their effects and the measures to prevent them in future. Int J Sci Technol Res. 2014;3:109-113.

4. Pandey S, Gautam R, Houweling S, van der Gon HD, Sadavarte P, Borsdorff $\mathrm{T}$, et al. Satellite observations reveal extreme methane leakage from a natural gas well blowout. Proc Natl Acad Sci. 2019;116: 26376-26381.

5. Bussmann I, Horn F, Hoppert M, Klings KW, Saborowski A, Warnstedt J, and Liebner, S. Methylomonas albis sp. nov. and Methylomonas fluvii sp. nov.: Two cold-adapted methanotrophs from the river Elbe and emended description of the species Methylovulum psychrotolerans. Syst and appl microbiol, 2021;44:126248.

6. Houghton KM, Carere CR, Stott MB and McDonald IR. Thermophilic methanotrophs: In hot pursuit. FEMS Microbiol Ecol. 2019;95: fiz125.

7. Takeuchi M, Kamagata Y, Oshima K, Hanada S, Tamaki H, Marumo K, Maeda H, Nedachi M, Hattori M, Iwasaki W, et al. Methylocaldum marinum sp. nov., a thermotolerant, methane-oxidizing bacterium isolated from marine sediments, and emended description of the genus Methylocaldum. Int J Syst Evol Microbiol. 2014;64:3240-3246.

8. Foster JW and Davis RH. A methane-dependent coccus, with notes on classification and nomenclature of obligate, methane-utilizing bacteria. $J$ Bacteriol. 1966;91:1924-1931.

9. Romanovskaya VA. Taxonomy of Methylotrophic. Biology of Methylotrophs. 2013;18:1.

10. Hirayama H, Fuse H, Abe M, Miyazaki M, Nakamura T, Nunoura T, Yasuo F, Hiroyuki Y and Takai K. Methylomarinum vadi gen. nov., sp. nov., a methanotroph isolated from two distinct marine environments. Int J Syst Evol Microbiol. 2013;63:1073-1082.

11. Bodrossy L, Holmes EM, Holmes AJ, Kovács KL and Murrell JC. Analysis of $16 \mathrm{~S}$ rRNA and methane monooxygenase gene sequences reveals a novel group of thermotolerant and thermophilic methanotrophs, Methylocaldum gen. nov. Arch Microbiol. 1997;168:493-503.

12. Bowman JP, Sly LI, Nichols PD and Hayward AC. Revised taxonomy of the methanotrophs: Description of Methylobacter gen. nov., emendation of Methylococcus, validation of Methylosinus and Methylocystis species, and a proposal that the family Methylococcaceae includes only the group I methanotrophs. Int J Syst Evol Microbiol. 1993;43: 735-753.
13. Tsyrenzhapova IS, Eshinimaev BT, Khmelenina VN, Osipov GA and Trotsenko YA. A new thermotolerant aerobic methanotroph from a thermal spring in Buryatia. Microbiology. 2007;76:118-121.

14. van Teeseling MC, Pol A, Harhangi HR, van der Zwart S, Jetten MS, den Camp HJO and van Niftrik L. Expanding the verrucomicrobial methanotrophic world: description of three novel species of Methylacidimicrobium gen. nov. Appl environ microbiol. 2014;80:67826791.

15. McDonald IR, Bodrossy L, Chen Y and Murrell JC. Molecular ecology techniques for the study of aerobic methanotrophs. Appl Environ Microbiol. 2008;74:1305-1315.

16. Lau E, Fisher MC, Steudler PA and Cavanaugh CM. The methanol dehydrogenase gene, $\mathrm{mxaF}$, as a functional and phylogenetic marker for proteobacterial methanotrophs in natural environments. PLoS ONE 2013;8: e56993.

17. Ward N, Larsen Ø, Sakwa J, Bruseth L, Khouri H, Durkin AS, Dimitrov G, Jiang L, Scanlan D, Kang KH, et al. Genomic insights into methanotrophy: The complete genome sequence of Methylococcus capsulatus (Bath). PLoS Biol. 2004;2: e303.

18. Dedysh SN, Berestovskaya YY, Vasylieva LV, Belova SE, Khmelenina VN, Suzina NE, Yuri AT, Werner L and Zavarzin GA. Methylocella tundrae sp. nov., a novel methanotrophic bacterium from acidic tundra peatlands. Int $J$ Syst Evol Microbiol. 2004;54:151-156.

19. Islam T, Torsvik V, Larsen Ø, Bodrossy L, Øvreås L and Birkeland NK. Acid-tolerant moderately thermophilic methanotrophs of the class Gammaproteobacteria i. solated from tropical topsoil with methane seeps. Front Microbiol. 2016;7:851.

20. Islam T, Larsen Ø, Torsvik V, Øvreås L, Panosyan H, Murrell JC, Birkeland NK and Bodrossy L. Novel methanotrophs of the family Methylococcaceae from different geographical regions and habitats. Microorganisms. 2015;3:484-499.

21. Van Der linde K, Lim BT, Rondeel JM, Antonissen LP and de Jong GM. Improved bacteriological surveillance of haemodialysis fluids: a compasion between Tryptic soya gar and Reasoner's 2A media. Nephrol Dial Trans. 1999;14:2433-2437.

22. Islam T, Jensen $\mathrm{S}$, Reigstad LJ Larsen $\mathrm{O}$ and Birkeland NK. Methane oxidation at 55 degrees $\mathrm{C}$ and $\mathrm{pH} 2$ by a thermoacidophilic bacterium belonging to the Verrucomicrobia phylum. Proc Natl Acad Sci. USA. 2008;105:300-304.

23. Bédard $\mathrm{C}$ and Knowles R. Physiology, biochemistry, and specific inhibitors of $\mathrm{CH}_{4}, \mathrm{NH}_{4}^{+}$, and $\mathrm{CO}$ oxidation by methanotrophs and nitrifiers. Microbiol Rev. 1989;53:68-84.

24. Graham D, Korich D, LeBlanc R, Sinclair N and Arnold R. Applications of a colorimetric plate assay for soluble methane monooxygenase activity. Appl Environ Microbiol. 1992;58:2231-2236.

25. Lane DJ. 16S/23S rRNA sequencing. John Wiley and Sons, Chichester, West Sussex, UK 1991.

26. Islam T, Gessesse A, Garcia-Moyano A, Murrell JC and Øvreås L. A novel moderately thermophilic type $\mathrm{Ib}$ methanotroph isolated from an alkaline thermal spring in the Ethiopian Rift Valley. Microorganisms. 2020;8:250.

27. Kumar S, Stecher G and Tamura K. MEGA7: Molecular Evolutionary Genetics Analysis Version 7.0. Mol Biol Evol. 2016;33:1870-1874.

28. Whittenbury R, Phillips KC and Wilkinson JF. Enrichment, isolation and some properties of methane-utilizing bacteria. J Gen Microbiol. 1970;61: 205-218.

29. Prior S and Dalton H. Acetylene as a suicide substrate and active site probe for methane monooxygenase from Methylococcus capsulatus (Bath). FEMS Microbiol Lett. 1985;29:105-109.

30. Dedysh SN, Belova SE, Bodelie, PL, Smirnova KV, Khmelenina VN, Chidthaisong A, Yuri AT, Werner L and Dunfield PF. Methylocystis heyeri sp. nov., a novel type II methanotrophic bacterium possessing 'signature'fatty acids of type I methanotrophs. Int J Syst Evol Microbiol. 2007;57: 472-479. 
31. Wartiainen I, Hestnes AG, McDonald IR and Svenning MM. Methylocystis rosea sp. nov., a novel methanotrophic bacterium from Arctic wetland soil, Svalbard, Norway ( $\left.78^{\circ} \mathrm{N}\right)$. Int J Syst Evol Microbiol. 2006;56:541-547.

32. Hoefman S, van der Ha D, Iguchi H, Yurimoto H, Saka Y, Boon N, Vandamme P, Heylen K and de Vos P. Methyloparacoccus murrellii gen. nov., sp. nov., a methanotroph isolated from pond water. Int J Syst Evol Microbiol. 2014;64:2100-2107.

33. Khalifa A, Lee CG, Ogiso T, Ueno C, Dianou D, Demachi T, Katayama A and Asakawa S. Methylomagnum ishizawai gen. nov., sp. nov., a mesophilic type I methanotroph isolated from rice rhizosphere. Int J Syst Evol Microbiol. 2015;65:3527-3534.

34. Guckert, JB, Ringelberg, DB, White, DC, Hanson, RS and Bratina, BJ. Membrane fatty acids as phenotypic markers in the polyphasic taxonomy of methylotrophs within the Proteobacteria. Microbiology, 1991;137: 2631-2641.

35. Iguchi, H, Yurimoto, H and Sakai Y. Methylovulum miyakonense gen. nov., sp. nov., a type I methanotroph isolated from forest soil. International journal of systematic and evolutionary microbiology. 2011;61:810-815.
36. Rattanachomsri U, Kanokratana P, Eurwilaichitr L, Igarashi Y and Champreda V. Culture-independent phylogenetic analysis of the microbial community in industrial sugarcane bagasse feedstock piles. Biosci biotechnol biochem. 2011;75:232-239.

37. Lin LH, Hall J, Onstott TC, Gihring T, Lollar BS, Boice E, Lisa P, Johanna LP and Bellamy RE. Planktonic microbial communities associated with fracture-derived groundwater in a deep gold mine of South Africa. Geomicrobiol J. 2006;23:475-497.

38. Costello AM and Lidstrom ME. Molecular characterization of functional and phylogenetic genes from natural populations of methanotrophs in lake sediments. Appl Environ Microbiol. 1999;65:5066-74.

39. Knief $\mathrm{C}$ and Dunfield PF. Response and adaptation of different methanotrophic bacteria to low methane mixing ratios. Environ Microbiol. 2005;7:1307-17.

40. Liu, J, Zheng, C, Song, C, Guo, S, Liu, X and Wang G. Conversion from natural wetlands to paddy field alters the composition of soil bacterial communities in Sanjiang Plain, Northeast China. Ann Microbiol. 2014.;64:1395-1403. 